\title{
PENGARUH PENGGUNAAN MEDIA PEMBELAJARAN DAN GAYA BELAJAR TERHADAP KEMAMPUAN MENYIMAK BAHASA INGGRIS (Studi Pada Siswa SMK Swasta Jakarta Pusat)
}

\author{
Yendri Deswin \\ Dosen Bahasa Inggris STIE Tri Guna \\ E-mail : yendri.deswin@yahoo.com
}

\begin{abstract}
This research aims to know how impact of using learning media and student learning style for the student English listening skill. This research was conducted by distributing questionnaires and term test directly of the Private Vocational School of Central Jakarta as using 50 students that choosing as simple random sampling technique. Data were analyzed by using descriptive statistic method, Parson oefficient, and regression analyze. Result of this research shows that using learning media and learning style for student significantly impact of capabilities of English listening skill student at vocational school in Central Jakarta

Keywords: learning media, learning style, listening skill
\end{abstract}

\section{PENDAHULUAN}

Kualitas pendidikan telah menjadi referensi utama dan keprihatinan di era globalisasi ini. Dalam konsep yang lebih luas, kualitas pendidikan mengacu pada proses dan hasil pendidikan secara keseluruhan. Dengan menetapkan standar kompetensi siswa pada penilaian siswa, pemerintah Indonesia memiliki standar kualitas pendidikan di sekolah kejuruan dengan menggelar ujian nasional. Meningkatkan mutu pendidikan dimulai dengan penentuan standar. Penentuan peningkatan standar terus menerus ini diharapkan dapat mendorong peningkatan kualitas pendidikan, yang merupakan penentuan standar pendidikan dan penentuan nilai batas. Seseorang dikatakan telah lulus/kompeten bila telah melewati nilai batas antara peserta didik yang telah menguasai kompetensi tertentu dengan peserta didik yang belum menguasai kompetensi tertentu. Bila itu terjadi pada ujian nasional atau sekolah maka fungsi nilai batas untuk memisahkan siswa yang lulus dan tidak lulus disebut batas kelulusan, pembatasan kelulusan disebut pengaturan standar. Manfaat ujian pengaturan standar akhir:

1. Batas kelulusan setiap mata pelajaran sesuai dengan tuntutan kompetensi minimum.

2. Standar yang sama untuk setiap mata pelajaran sebagai standar minimum pencapaian kompetensi. 
Tujuan dari penelitian ini difokuskan untuk mengukur pandangan bahwa penilaian siswa adalah bagian penting dari pengajaran dan pengajaran yang baik tidak dapat eksis tanpa penilaian murid yang baik. Bahasa Inggris adalah salah satu subjek yang termasuk dalam ujian. Di sisi lain, cukup banyak siswa yang tidak mampu lulus tes bahasa Inggris. Selain itu, yang terjadi di sekolah, adalah bahwa mereka harus mengikuti banyak item tes bahasa Inggris. Seperti Listening dan Reading Speaking dan Writing sehingga mereka terasa berupaya keras dalam test tersebut. Sebagai contoh, siswa di SMK Kartini Jakarta Pusat mulanya tidak merasa pentingnya tes praktek bahasa Inggris, padahal Listening (Menyimak) Test, tertuang dalam kurikulum sekolah. Yang merupakan tujuan pembelajaran.

Media pembelajaran dan gaya belajar yang baik akan meningkatkan kemampuan menyimak Bahasa Inggris peserta didik yang bertujuan meningkatkan daya rangsang peserta didik dalam mengingat apa yang sudah di pelajari dan menimbulkan rangsangan baru.

Untuk trampil dalam menyimak pada pembelajaran bahasa Inggris para peserta didik sekolah menengah kejuruan khususnya SMK Kartini Jakarta pusat, umumnya mengalami kesulitan dan membutuhkan waktu lama,hal ini seringkali menjadi kendala, untuk trampil menyimak melibatkan proses membaca, memahami dan menginterpretasi yang membutuhkan waktu lama, karena kurangnya media.

Proses membiasakan siswa dan upaya meningkatkan kemampuan menyimak bahasa Inggris dimulai dengan upaya-upaya yang bertujuan agar peserta didik harus kreatif dan membiasakan diri dalam mulai menyimak pembicaraan-pembicaraan bahasa Inggris di media-media yang tersedia. Upaya tersebut diantara menggunakan metode dan gaya pembelajaran yang kreatif, inovatif dan variatif juga menggunakan media yang menarik dan menyenangkan dari beragam media pembelajaran.

Berbicara tentang pencapaian target bahasa, ada beberapa unsur, salah satu unsur utama adalah gaya belajar. Pengalaman menunjukkan bahwa negara-negara maju adalah mereka yang menempatkan Learning Style (Gaya Belajar) sebagai unsur utama dalam pendidikan. Di Indonesia, belum ditempatkan secara tepat dalam kebijakan dan program pendidikan. Sekarang ini adalah waktu untuk membuat kebijakan dengan paradigma baru, yang membangun pendidikan dengan memulainya dari subyek "gaya pengajaran yang baik serta dengan menggunakan media pembelajaran yang kreatif 
". Tanpa itu, kualitas pendidikan yang dimaksudkan untuk mendidik masyarakat melalui pengembangan sumber daya manusia tidak akan tercapai. dan gaya belajar siswa merupakan alternatif yang dapat siap di lakukan di kelas, guru dapat menggunakan berbagai media untuk membuat siswa terbiasa dan mempraktikkan dengan menggunakan berbagai latihan item untuk memudahkan siswa memahami kemampuan menyimak bahasa Inggris.

Peneliti telah lama melaporkan manfaat menggunakan Media dalam pengajaran bahasa. Satu dekade terakhir telah terlihat meningkatnya minat dalam mengeksplorasi Media sebagai alat pengajaran dalam silabus berbasis konten, media yang di pakai terutama untuk sekolah kejuruan.

Ini berarti, para guru harus menggunakan dan mengeksplorasi banyak bahan sebagai sumber daya dan metode memungkin untuk memperbaiki bahasa Inggris mereka. Guru harus menciptakan suatu lingkungan di mana mereka dihadapkan ke bahasa Inggris setiap hari. Misalnya, guru meminta siswa untuk mendengarkan Voice of America, menonton televisi di CNN, BBC atau SkyNews, membaca artikel surat kabar dalam bahasa Inggris dan menulis e-mail. Selain itu, Internet menyediakan dengan berbagai macam alat belajar seperti newsletter elektronik, kelompok diskusi dan forum.

Pengajaran menyimak bahasa Inggris ini telah mulai diajarkan di kelas X SMA pada semester ganjil. Dan pengajaran ini merupakan mata pelajaran yang wajib diberikan kepada siswa. Pengajaran ini membutuhkan kenyamanan situasi yang menyenangkan media yang memadai . Namun, pada kenyataannya pengajaran menyimak banyak yang beranggapan masih mudah dan gampang, dan siswa kita dianggap mampu.

\section{KERANGKA TEORITIS DAN HIPOTESIS}

\section{Media pembelajaran}

Pada umumnya media pembelajaran dapat digunakan untuk:1) Merekam dan menyimpan data atau informasi. 2) Memanipulasi aneka obyek. 3) Menyebarluaskan data atau informasi. 4) Mendampingi siswa dalam mengolah materi pelajaran baru atau mengolah kembali materi pelajaran lama. (W.S Winkel, 1996:286) 
Fungsi media pengajaran adalah : 1) Membantu memudahkan belajar bagi siswa dan membantu memudahkan mengajar bagi guru. 2) Memberikan pengalaman lebih nyata (yang abstrak dapat lebih konkrit). 3) Menarik perhatian siswa lebih besar (Jalannya pelajaran tidak membosankan). 4) Semua indera murid dapat diaktifkan. 5) Kelemahan satu indera dapat diimbangi oleh kekuatan indera lainnya. Lebih menarik perhatian dan minat murid dalam belajar. 6) Dapat membangkitkan dunia teori dengan realitanya. (Basyiruddin Usman dan Asnawir, 2002:24)

Fungsi media dapat dikategorikan pada, a) Penggunaan media dalam proses belajar mengajar bukan merupakan fungsi tambahan, tetapi mempunyai fungsi sendiri sebagai alat bantu untuk mewujudkan situasi belajar mengajar yang efektif. b) Penggunaan media pembelajaran merupakan bagian yang integral dari keseluruhan situasi mengajar. c) Media pembelajaran dalam pengajaran, penggunaannya integral dalam tujuan dan isi pelajaran. d) Penggunaan media dalam pelajaran bukan sematamata alat hiburan, dalam arti digunakan hanya sekedar melengkapi proses belajar supaya lebih menarik perhatian siswa. e) Penggunaan media dalam pelajaran lebih diutamakan untuk mempercepat proses belajar mengajar dan membantu siswa dalam menangkap pengertian yang diberikan guru. f)Penggunaan media dalam pelajaran diutamakan untuk mempertinggi mutu belajar mengajar “. (Syaiful Bahri Djamarah dan Aswan Zair, 2002:152)

Sementara itu Rowiszowski merumuskan: Media pembelajaran sebagai penyampaian pesan (carries of information) berinteraksi dengan siswa melalui alat penginderaannya. Siswa dapat juga dipanggil untuk menerima informasi, atau dapat juga menggunakan kombinasi alat indera sekaligus sehingga kegiatan berkomunikasi lebih seksama.

Prinsip-prinsip dalam pemilihan media pembelajaran, a) Jenis kemampuan yang akan dicapai, sesuai dengan tujuan pembelajaran (TIK). b) Kegunaan dari berbagai jenis media itu sendiri. c) Kemampuan guru menggunakan suatu jenis media. d) Keluwesan atau fleksibilitas dalam penggunaannya. e) Kesesuaian dengan alokasi waktu dan sarana pendukung yang ada. f) Ketersediaannya. g)Biaya. (R. Ibrahim dan Nana Syaodih, 2003:120)

Keuntungan-keuntungan mempergunakan media pembelajaran dalam pembelajarkan siswa menurut Heinrich, Molenda dan Russel (1982), a] Media 
pembelajaran dapat mengkonkritkan ide-ide atau gagasan yang bersifat konseptual, sehingga mengurangi kesalahpahaman siswa dalam mempelajarinya. b] Media pembelajaran dapat meningkatkan minat siswa untuk mempelajari materi pelajaran. c] Media pembelajaran dapat memberikan pengalaman-pengalaman nyata yang merangsang aktivitas diri sendiri untuk belajar. d] Media pembelajaran dapat mengembangkan jalan pikiran yang berkelanjutan. e] Media pembelajaran menyediakan pengalaman-pengalaman yang tidak mudah didapat melalui materimateri yang lain dan menjadikan proses belajar mendalam dan beragam.

Nilai-nilai praktis media pembelajaran menurut Nana Sudjana yang dikemukan oleh Syaiful Basri, a) Dengan media dapat meletakkan dasar-dasar yang nyata untuk berpikir. b) Dengan media dapat memperbesar minat dan perhatian siswa untuk belajar. c) Dengan media dapat meletakkan dasar untuk perkembangan belajar sehingga hasil belajar bertambah mentap. d) Memberikan pengalaman yang nyata dan dapat menumbuhkan kegiatan berusaha sendiri pada setiap siswa. e) Menumbuhkan pemikiran yang teratur dan berkesinambungan. f) Membantu tumbuhnya pemikiran dan dan membantu berkembangnya kemampuan berbahasa. g) Memberikan pengalaman yang tak mudah diperoleh dengan cara lain serta membantu berkembangnya efisiensi dan pengalaman belajar yang lebih sempurna. h) Bahan pembelajaran akan lebih jelas maknanya, sehingga dapat lebih dipahami oleh para siswa, dan memungkinkan siswa menguasai tujuan pengajaran lebih baik. i) Metode Mengajar akan lebih bervariasi, tidak semata-mata komunikasi verbal melalui penuturan kata-kata oleh guru, sehingga siswa tidak bosan dan guru tidak kehabisan tenaga, apalagi bila guru mengajar untuk setiap jam pelajaran. j) Siswa lebih banyak melakukan kegiatan belajar, sebab tidak hanya mendengarkan uraian guru, tetapi juga aktivitas lain seperti mengamati, melakukan, mendemonstrasikan dan lain-lain. (Syaiful Bahri Djamarah dan Aswan Zair, 2002:155)

Dengan dikemukakannya pendapat para ahli maka dapat disimpulkan bahwa media pembelajaran memang memiliki peranan yang sangat penting dalam membantu siswa dalam belajar. Penggunaan media pembelajaran memang memiliki peranan yang sangat penting dalam membantu siswa dalam belajar. Dari definisi yang telah dikemukakan di atas maka penggunaan media pembelajaran adalah seperangkat yang mempunyai fungsi dan manfaat dalam menyampaikan informasi kepada audiens dalam 
hal ini siswa, melalui proses belajar mengajar sehingga mempermudah siswa dalam belajar.

Media juga dapat dibagi menjadi media yang didengar atau audio (auditory), media yang dilihat (visual), dan media yang didengarkan dan dilihat (audio-visual).

Sudirman, dkk. (1992: 206-207) menguraikan lebih jelas media auditif, media visual, dan media audiovisual sebagai berikut : a/ Media auditif/audio, yaitu media yang hanya mengandalkan kemampuan suara saja, seperti radio, tape-recorder/casette recorder, piringan audio. Media ini tidak cocok untuk orang yang tuli atau mempunyai kelainan dalam pendengaran. b/ Media visual, yaitu media yang hanya mengandalkan indera penglihatan. Media visual ini ada yang menampilkan gambar diam seperti film strip (film rangkai), slides (film bingkai) foto, gambar atau lukisan, cetakan. c/ Media audiovisual, yaitu media yang mempunyai unsur suara dan unsur gambar. Jenis media ini seperti film bingkai suara (sound slide) film rangkai suara, cetak suara, film suara dan videocassette.

\section{Gaya Belajar}

Dalam menyikapi berbagai macam mengenai gaya belajar, tentulah harus ditambah dengan logika dan kebudayaan cara kerja kita, dan yang paling penting dari semua diatas adalah suatu cara kerja otak kita yang mana dalam hal ini kita sebut dengan modalitas belajar. Secara singkat modalitas belajar adalah, suatu cara bagaimana otak menyerap informasi yang masuk melalui panca indera secara optimal. Menurut Howard Gardner modalitas belajar tersebut dapat dikarakteristik menjadi gaya belajar Auditory, Visual, Reading dan Kinestetik.

Pengertian gaya belajar menurut DePorter (2008 :112), “ gaya belajar adalah kombinasi dari bagaimana seseorang itu menyerap dan kemudian mengatur serta mengolah informasi". Jadi, setiap siswa memiliki gaya belajar yang berbedabeda. Terdapat tiga modalitas belajar seseorang yaitu : "modalitas visual, auditori atau kinestetik (V-AK). Walaupun masingmasing dari kita belajar dengan menggunakan ketiga modalitas ini pada tahapan tertentu, kebanyakan orang lebih cenderung pada salah satu di antara ketiganya". 
Auditory, belajar dengan mengandalkan pendengaran untuk bisa memahami sekaligus mengingatnya. Mereka yang memiliki gaya belajar ini umumnya susah menyerap secara langsung informasi dalam bentuk tulisan, selain memiliki kesulitan menulis ataupun membaca. ciri cirinya, a). Mampu mengingat dengan baik materi yang didiskusikan dalam kelompok, b). Mengenal banyak sekali lagu / iklan TV, c). Suka berbicara, d). Pada umumnya bukanlah pembaca yang baik, d). Kurang dapat mengingat dengan baik apa yang baru saja dibacanya, e). Kurang baik dalam mengerjakan tugas mengarang/menulis, f). Kurang memperhatikan hal-hal baru dalam lingkungan sekitarnya.

Visual, belajar dengan menitikberatkan ketajaman penglihatan. Cirri cirinya : a). Senantiasa melihat memperhatikan gerak bibir seseorang yang berbicara kepadanya, b). Cenderung menggunakan gerakan tubuh saat mengungkapkan sesuatu, c). Kurang menyukai berbicara di depan kelompok, dan kurang menyukai untuk mendengarkan orang lain, d). Biasanya tidak dapat mengingat informasi yang diberikan secara lisan, e). Lebih menyukai peragaan daripada penjelasan lisan, f). Biasanya orang yang Visual dapat duduk tenang di tengah situasi yang ribut/ramai tanpa merasa terganggu

Kinestetik mengharuskan individu yang bersangkutan menyentuh sesuatu yang memberikan informasi tertentu agar ia bisa mengingatnya. Ciri cirinya, a). Suka menyentuh segala sesuatu yang dijumpainya, b). Sulit untuk berdiam diri, c). Suka mengerjakan segala sesuatu dengan menggunakan tangan, d). Biasanya memiliki koordinasi tubuh yang baik, e). Suka menggunakan objek yang nyata sebagai alat bantu belajar, f). Mempelajari hal-hal yang abstrak merupakan hal yang sangat sulit.

\section{Menyimak}

Menyimak yang dianggap sebagai tape recorder manusia. Mereka mengambil sedikit informasi. Diadakan di dalamnya semacam memori jangka menengah, dan menggunakannya. Menyimak secara aktif memperhatikan dan fokus pada pemahaman setiap yang di dengar. Menyimak lebih merupakan proses daripada produk yang langsung membentuk pemahaman dan ucapan-ucapan dari para peserta didik

Menyimak terdiri keterampilan beberapa komponen yang, a) Membedakan antara suara. b) Mengenali kata-kata. c) Mengidentifikasi pengelompokan gramatikal kata-kata, e) Mengidentifikasi ekspresi dan mengatur ucapan-ucapan yang mempunyai makna f) Menghubungkan isyarat linguistik terhadap isyarat non-linguistik dan 
paralinguistik. g) Penggunaan latar belakang pengetahuan untuk memprediksi dan kemudian untuk mengkonfirmasi makna dan mengingat kata-kata penting dan ide-ide. Menyimak yang benar itu adalah proses aktif yang memiliki tiga langkah dasar, cukup mendengarkan, memahami, menilai.

\section{METODOLOGI PENELITIAN}

\section{Metode Penelitian}

Metode penelitian adalah cara yang digunakan dalam mengumpulkan data penelitian. Metode yang digunakan dalam penelitian ini adalah metode survey dengan analisis korelasi regresi. Data-data dalam penelitian ini diperoleh berdasarkan test hasil belajar Bahasa Inggris siswa dengan menggunakan media pembelajaran, hasil nilai try out siswa kelas XII dan pemberian angket gaya belajar dan Kemampuan menyimak Bahasa Inggris siswa dengan jumlah sampel 50 siswa.

\section{Desain Penelitian}

Desain penelitian yang penulis gunakan adalah sebagai berikut:

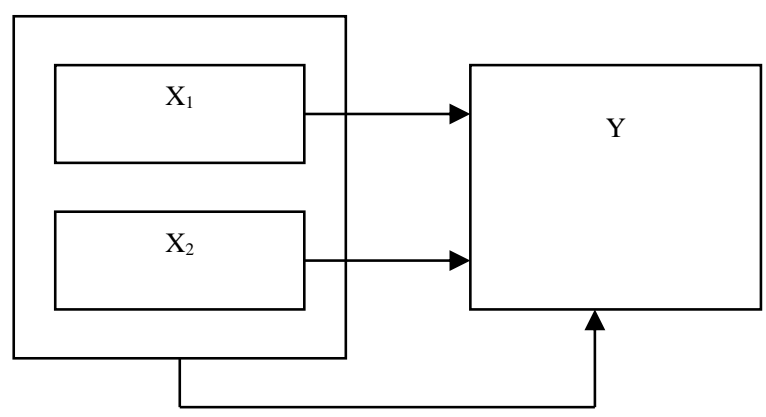

Keterangan:

$\mathrm{X}_{1}$ : Penggunaan Media Pembelajaran

$\mathrm{X}_{2}$ : Gaya Belajar

Y : Kemampuan Menyimak Bahasa Inggris

\section{HASIL PENELITIAN DAN PEMBAHASAN}

\section{Deskripsi Data Hasil Penelitian}

Penelitian ini dilakukan pada 50 orang siswa kelas XII SMK Kartini 1, dan SMK Muhammadiyah Jakarta Pusat pada tahun pelajaran 2013/2014. Penelitian ini terdiri atas 3 variabel, yaitu variabel kemampuan menyimak bahasa Inggris sebagai variabel 
terikat $(\mathrm{Y})$, penggunaan media pembelajaran $\left(\mathrm{X}_{1}\right)$, dan gaya belajar $\left(\mathrm{X}_{2}\right)$ sebagai variabel bebas. Deskripsi data secara keseluruhan yang diolah dengan bantuan progam SPSS

Tabel 1. Deskripsi Data Variabel Penelitian

Statistics

\begin{tabular}{lrrr}
\hline & $\begin{array}{c}\text { Kemampuan } \\
\text { Menyimak }\end{array}$ & $\begin{array}{c}\text { Penggunaan } \\
\text { Media }\end{array}$ & $\begin{array}{c}\text { Gaya } \\
\text { Belajar }\end{array}$ \\
\hline$N$ & 50 & 50 & 50 \\
\cline { 2 - 4 } Valid Missing & 0 & 0 & 0 \\
\hline Mean & 66.6200 & 26.1200 & 41.6800 \\
\hline Median & 68.0000 & 26.5000 & 42.0000 \\
\hline Mode & 70.00 & $24.00^{a}$ & 45.00 \\
\hline Std. Deviation & 7.90218 & 3.49133 & 4.65741 \\
\hline Variance & 62.444 & 12.189 & 21.691 \\
\hline Range & 36.00 & 17.00 & 17.00 \\
\hline Minimum & 50.00 & 18.00 & 34.00 \\
\hline Maximum & 86.00 & 35.00 & 51.00 \\
\hline a. Multiple modes exist. The smallest value is shown
\end{tabular}

\section{Data Kemampuan menyimak bahasa Inggris}

Data variabel kemampuan menyimak bahasa Inggris diperoleh dari nilai hasil ulangan umum yang dicapai siswa dalam proses belajar menyimak bahasa Inggris. Maka, dapat disimpulkan kemampuan menyimak bahasa Inggris bahasa Inggris siswa kelas XII Sekolah Menengah Kejuruan Swasta di Jakarta Pusat dalam kategori cukup baik. Secara visual sebaran datanya dapat dilihat pada histogram berikut ini.

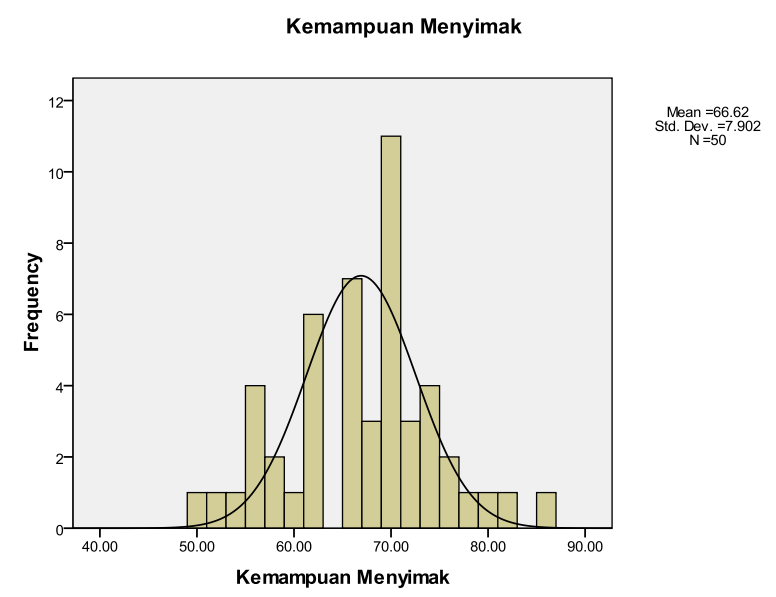

Gambar 1. Histogram Data Kemampuan Menyimak 


\section{Deskripsi Data Penggunaan Media Pembelajaran}

Penggunaan media pembelajaran adalah tanggapan siswa tentang penggunaan media dalam pembelajaran bahasa Inggris. Penggunaan media pembelajaran diantaranya meliputi 1). Media auditif/audio, yaitu media yang hanya mengandalkan kemampuan suara saja, 2) Media visual, yaitu media yang hanya mengandalkan indera penglihatan. Media visual ini ada yang menampilkan gambar diam seperti film strip, slides foto, gambar atau lukisan, cetakan, dan 3) media audiovisual, yaitu media yang mempunyai unsur suara dan unsur gambar.

Data variabel penggunaan media pembelajaran (variabel bebas $\mathrm{X}_{1}$ ) diperoleh dari hasil kuesioner sebanyak 8 butir dengan lima pilihan jawaban (selalu, sering, kadang-kadang, jarang, dan tidak pernah) tentang penggunaan media pembelajaran diantaranya media auditif, media visual, dan media audiovisual. sehingga memiliki skor teoritik terendah 8 dan skor tertinggi 40.

Dari hasil analisis data untuk variabel penggunaan media pembelajaran diperoleh skor tertinggi 35 dan skor terendah 18, keragaman datanya ditunjukkan dengan adanya nilai variansi 12,19 dan standar deviasinya 3,49. Data dari variabel ini mempunyai nilai rata-rata sebesar 26,12, dan median 26,50. Berdasarkan data tersebut, disimpulkan penggunaan media pembelajaran siswa kelas XII Sekolah Menengah Kejuruan Swasta di Jakarta Pusat dalam kategori cukup. Secara visual sebaran datanya pada histogram berikut ini.

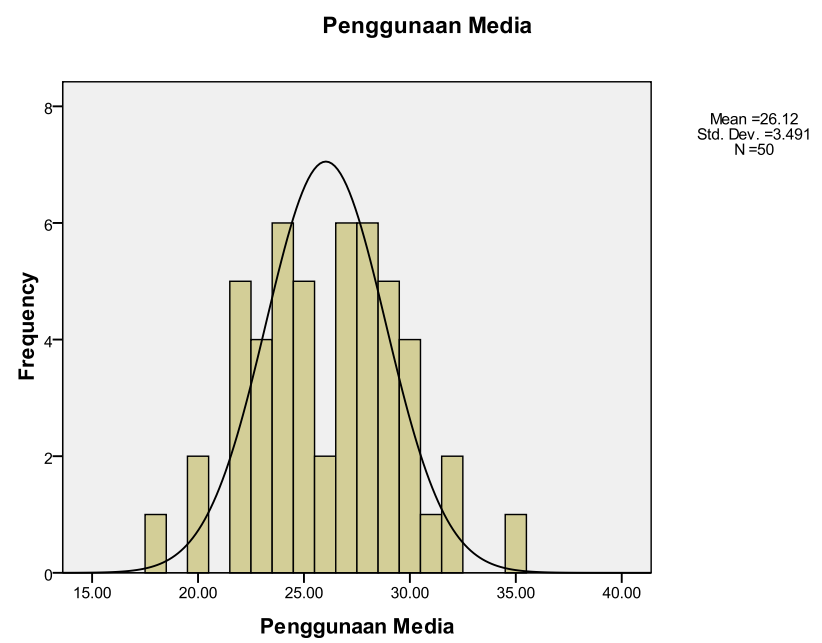

Gambar 2. Histogram Data Penggunaan Media 


\section{Deskripsi Data Gaya Belajar}

Gaya belajar siswa adalah suatu kombinasi dari bagaimana ia menyerap, dan kemudian mengatur serta mengolah informasi. Gaya belajar bukan hanya berupa aspek ketika menghadapi informasi, melihat, mendengar, menulis dan berkata tetapi juga aspek pemrosesan informasi sekunsial, analitik, global atau otak kiri- otak kanan, aspek lain adalah ketika merespon sesuatu atas lingkungan belajar (diserap secara abstrak dan konkret).

Sementara itu, deskripsi data variabel gaya belajar diperoleh dari hasil dari hasil kuesioner sebanyak 13 butir dengan lima pilihan jawaban (selalu, sering, kadangkadang, jarang, dan tidak pernah) tentang gaya belajar. sehingga memiliki skor teoritik terendah 13 dan skor tertinggi 65.

Dari hasil analisis data untuk variabel gaya belajar diperoleh skor tertinggi 51 skor terendah 34, keragaman datanya ditunjukkan dengan adanya nilai variansi 21,69, dan standar deviasinya 4,66. Data dari variabel ini mempunyai nilai rata-rata sebesar 41,68, dan median 42,00. Hal ini menunjukkan bahwa gaya belajar siswa siswa kelas XII Sekolah Menengah Kejuruan Swasta di Jakarta Pusat dalam kategori cukup baik. Secara visual sebaran datanya dapat dilihat pada histogram berikut ini.

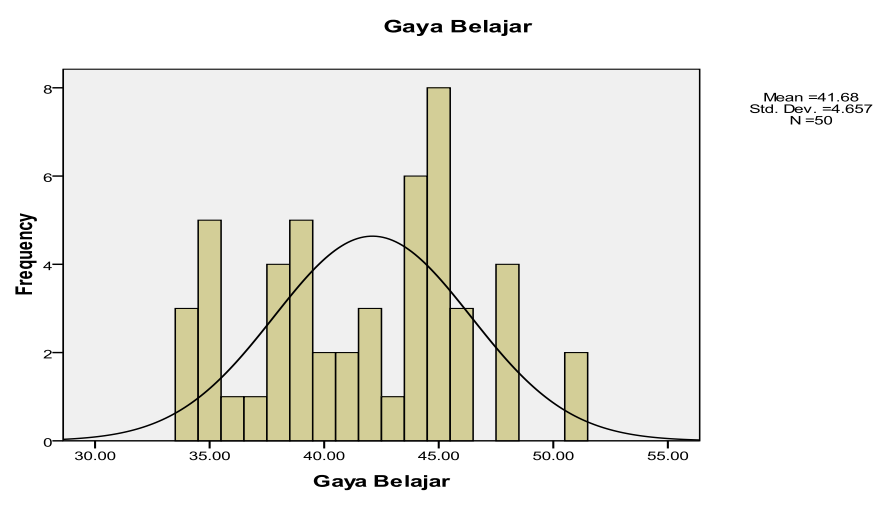

Gambar 3. Histogram Data Gaya Belajar

\section{Pengujian Persyaratan Analisis}

Pengujian analisis regresi linear, mempunyai beberapa persyaratan analisis. A) Sampel yang berupa pasangan data $X_{1}$ dan $X_{2}$ harus diambil acak dan memenuhi sampel minimum. B) Untuk setiap kelompok harga predictor $\mathrm{X}_{1}$ yang diberikan, respons-respons $X_{2}$ harus independen dan berdistribusi normal. C) Untuk setiap kelompok $\mathrm{X}_{1}$, variabel $\mathrm{S}^{2}$ harus homogen (sama) D) Bentuk regresi adalah linear. 
Dengan ukuran sampel acak sebanyak 50 orang. kemudian syarat bentuk linear persamaan regresi pengujiannya dilakukan secara bersama-sama dengan pengujian hipotesis.Data tersebut baru valid untuk tujuan pengujian hipotesis jika data tersebut mempunyai asumsi distribusi normal dan bersifat homogen. Oleh karena itu, perlu dilakukan pengujian normalitas galat taksiran, persamaan regresi dan homogenitas. Uji normalitas dilakukan dengan metode Kolmogorov-Smirnov dengan bantuan program SPSS 17.

\section{Uji Persyaratan Normalitas}

\section{Pengujian Normalitas Variabel $Y, X_{1}$, dan $X_{2}$}

Tabel 2. One-Sample Kolmogorov-Smirnov Test

\begin{tabular}{llrrr}
\hline & & $\begin{array}{c}\text { Kemampuan } \\
\text { Menyimak }\end{array}$ & $\begin{array}{c}\text { Penggunaan } \\
\text { Media }\end{array}$ & $\begin{array}{c}\text { Gaya } \\
\text { Belajar }\end{array}$ \\
\hline$N$ & 50 & 50 & 50 \\
\hline Normal Parameters $^{a, b}$ & Mean & 66.6200 & 26.1200 & 41.6800 \\
\cline { 2 - 5 } & Std. Deviation & 7.90218 & 3.49133 & 4.65741 \\
\hline Most Extreme & Absolute & .109 & .099 & .151 \\
\cline { 2 - 5 } Differences & Positive & .082 & .088 & .097 \\
\cline { 2 - 6 } & Negative & -.109 & -.099 & -.151 \\
\hline Kolmogorov-Smirnov Z & & .773 & .704 & 1.066 \\
\hline Asymp. Sig. (2-tailed) & .589 & .705 & .206 \\
\hline a. Test distribution is Normal. & & & \\
b. Calculated from data. & & & \\
\end{tabular}

Dari tabel di atas dapat diketahui nilai sig untuk variabel $\mathrm{Y}, \mathrm{X}_{1}$, dan $\mathrm{X}_{2}$, berturutturut adalah 0,589, 0,705, dan 0,206. Jika dibandingkan dengan kriteria pengujian normalitas Kolmogorov-Smirnov, ketiga variabel tersebut berdistribusi normal, karena memiliki nilai $>0,05$.

Untuk memperkuat hasil pengujian tersebut juga ditampilkan Grafik Normal QQ Plot untuk setiap variabel sebagai berikut: 
Normal Q-Q Plot of Kemampuan Menyimak

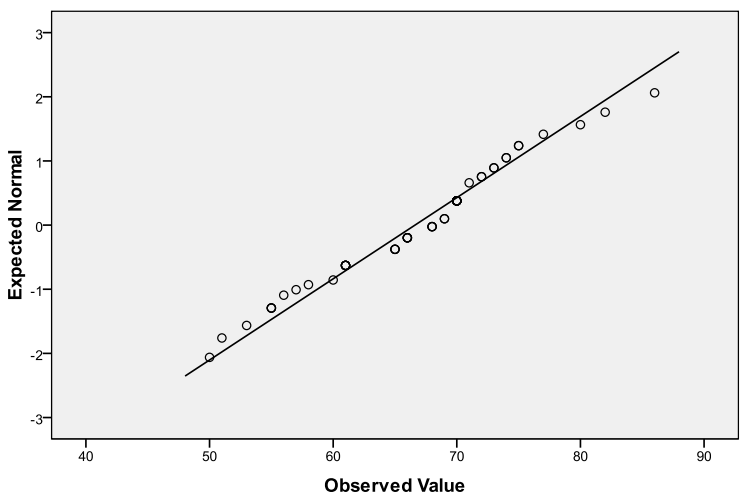

\section{Grafik Normal Q-Q Plot Variabel Kemampuan Menyimak}

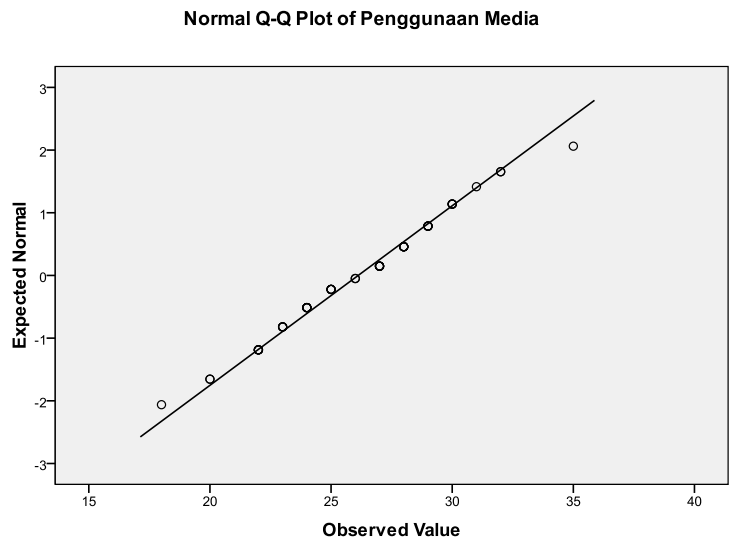

Gambar 4. Grafik Normal Q-Q Plot Variabel Penggunaan Media

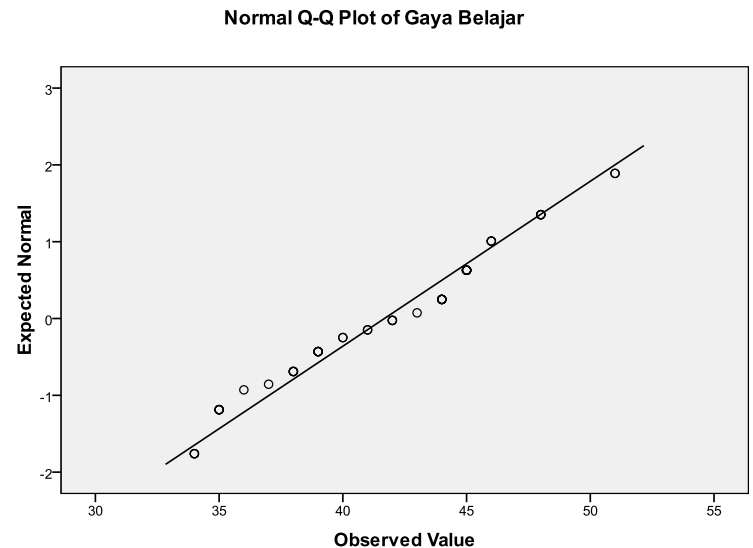

Gambar 5. Grafik Normal Q-Q Plot Variabel Gaya Belajar 


\section{Uji Linieritas Regresi}

Uji linearitas dilakukan untuk melihat persamaan regresi $\mathrm{Y}=\mathrm{a}+\mathrm{bX}$ berbentuk linear. Dalam analisis ini menggunakan program SPSS for windows 17.0. Untuk menentukan bahwa persamaan regresi linear atau tidak dengan melihat koefisien $P$ value, yaitu apabila koefisien $P$-value lebih besar dari taraf signifikansi 0,05, persamaan regresi berbentuk linear. Sebaliknya, apabila koefisien $P$-value lebih kecil daripada taraf signifikansi 0,05, persamaan regresi berbentuk tidak linear.

Uji linearitas dalam penelitian ini meliputi uji linearitas persamaan regresi kemampuan menyimak bahasa Inggris atas penggunaan media pembelajaran ( $\mathrm{Y}$ atas $\mathrm{X}_{1}$ ) dan uji linearitas persamaan regresi kemampuan menyimak bahasa Inggris atas gaya belajar ( $\mathrm{Y}$ atas $\mathrm{X}_{2}$ ). Berikut adalah hasil pengujiannya.

\section{Uji linearitas regresi kemampuan menyimak atas penggunaan media} pembelajaran

Tabel 3. ANOVA Table

\begin{tabular}{|c|c|c|c|c|c|c|c|}
\hline & & & $\begin{array}{l}\text { Sum of } \\
\text { Squares }\end{array}$ & $d f$ & $\begin{array}{l}\text { Mean } \\
\text { Square }\end{array}$ & $F$ & Sig. \\
\hline \multirow{5}{*}{$\begin{array}{l}\text { Kemampuan Menyimak } \\
\text { * Penggunaan Media }\end{array}$} & \multirow{3}{*}{$\begin{array}{l}\text { Between } \\
\text { Groups }\end{array}$} & (Combined) & 1990.213 & 13 & 153.093 & 5.153 & .000 \\
\hline & & Linearity & 1746.271 & 1 & 1746.271 & 58.777 & .000 \\
\hline & & $\begin{array}{l}\text { Deviation } \\
\text { from } \\
\text { Linearity }\end{array}$ & 243.942 & 12 & 20.329 & .684 & .755 \\
\hline & \multicolumn{2}{|c|}{ Within Groups } & 1069.567 & 36 & 29.710 & & \\
\hline & \multicolumn{2}{|l|}{ Total } & 3059.780 & 49 & & & \\
\hline
\end{tabular}

Dari tabel di atas diketahui besarnya nilai sig pada baris deviation from linearity adalah 0,755 yang berarti lebih besar daripada 0,05 . Karena nilai sig > 0,05, maka bentuk persamaan regresi kemampuan menyimak bahasa Inggris atas penggunaan media pembelajaran adalah linier. 


\section{Uji linieritas regresi kemampuan menyimak atas gaya belajar}

Tabel 4. ANOVA Table

\begin{tabular}{|c|c|c|c|c|c|c|c|}
\hline & & & $\begin{array}{l}\text { Sum of } \\
\text { Squares }\end{array}$ & $d f$ & $\begin{array}{l}\text { Mean } \\
\text { Square }\end{array}$ & $F$ & Sig. \\
\hline \multirow{5}{*}{$\begin{array}{l}\text { Kemampuan Menyimak * } \\
\text { Gaya Belajar }\end{array}$} & \multirow{3}{*}{$\begin{array}{l}\text { Between } \\
\text { Groups }\end{array}$} & (Combined) & 1945.772 & 14 & 138.984 & 4.367 & .000 \\
\hline & & Linearity & 1711.938 & 1 & 1711.938 & 53.786 & .000 \\
\hline & & $\begin{array}{l}\text { Deviation } \\
\text { from } \\
\text { Linearity }\end{array}$ & 233.833 & 13 & 17.987 & .565 & .865 \\
\hline & \multicolumn{2}{|c|}{ Within Groups } & 1114.008 & 35 & 31.829 & & \\
\hline & \multicolumn{2}{|l|}{ Total } & 3059.780 & 49 & & & \\
\hline
\end{tabular}

Dari tabel di atas diketahui besarnya nilai sig pada baris deviation from linearity adalah 0,865 yang berarti lebih besar dari 0,05. Karena nilai sig > 0,05, maka bentuk persamaan regresi kemampuan menyimak bahasa Inggris atas gaya belajar adalah linier.

\section{Uji Multikolinieritas}

Uji multikolinearitas bertujuan untuk menguji apakah model regresi ditemukan adanya korelasi yang sempurna antar variabel bebas (independen).Model regresi yang baik seharusnya tidak terjadi korelasi yang sempurna di antara variabel bebas. Salah satu cara untuk mendeteksi adanya multikolinearitas adalah dengan melihat tolerance atau Varians Inflation Factor (VIF). Apabila tolerance lebih kecil dari 0,1 atau nilai VIF di atas 10, maka terjadi multikolinearitas. Aturan yang berikutnya adalah jika nilai Tol dan VIF mendekati angka satu maka dalam analisis regresi ganda tak ada multikoliniaritas.

Hasil uji multikolinearitas pada pada tabel di bawah diketahui bahwa hasil Tolerance dan nilai Varians Inflation Factor (VIF) pada masing-masing variabel mendekati nilai angka satuyaitu 0,273 dan 2,681. Sehingga dapat dinyatakan bahwa tidak ada multikolinieritas antara variabel Penggunaan media dan variabel gaya belajar pada analisis regresi ganda ini. 
Tabel. 5 Uji Multikolinieritas

\begin{tabular}{|c|c|c|c|}
\hline \multirow{2}{*}{\multicolumn{2}{|c|}{ Model }} & \multicolumn{2}{|c|}{ Collinearity Statistics } \\
\hline & & Tolerance & $V I F$ \\
\hline \multirow[t]{3}{*}{1} & (Constant) & & \\
\hline & $\begin{array}{l}\text { Penggunaan } \\
\text { media }\end{array}$ & .273 & 2.681 \\
\hline & Gaya belajar & .273 & 2.681 \\
\hline
\end{tabular}

\section{Pengujian Hipotesis Penelitian}

Uji signifikansi koefisien korelasi dan uji signifikansi koefisien korelasi ganda.

\section{Hasil Perhitungan Koefisien Korelasi Pengaruh Variabel $X_{1}$ dan $X_{2}$ terhadap}

\section{Variabel Y}

Tabel 6. Model Summary

\begin{tabular}{|l|c|r|r|c|}
\hline Model & $R$ & $\begin{array}{c}R \\
\text { Square }\end{array}$ & $\begin{array}{c}\text { Adjusted } R \\
\text { Square }\end{array}$ & $\begin{array}{c}\text { Std. Error of the } \\
\text { Estimate }\end{array}$ \\
\hline 1 & $.794^{a}$ & .631 & .615 & 4.90213 \\
\hline
\end{tabular}

a. Predictors: (Constant), Gaya Belajar, Penggunaan Media

\section{Hasil Perhitungan Pengujian Signifikasi Koefisien Regresi Pengaruh Variabel $\mathrm{X}_{1}$} dan $\mathrm{X}_{2}$ dengan Variabel $\mathrm{Y}$

Tabel 7. $A N O V A^{b}$

\begin{tabular}{|c|c|c|c|c|c|}
\hline Model & $\begin{array}{l}\text { Sum of } \\
\text { Squares }\end{array}$ & $d f$ & $\begin{array}{l}\text { Mean } \\
\text { Square }\end{array}$ & $F$ & Sig. \\
\hline $\begin{array}{l}\text { Regressi } \\
\text { on }\end{array}$ & 1930.327 & 2 & 965.164 & 40.163 & $.000^{a}$ \\
\hline Residual & 1129.453 & 47 & 24.031 & & \\
\hline Total & 3059.780 & 49 & & & \\
\hline
\end{tabular}

a. Predictors: (Constant), Gaya Belajar, Penggunaan Media

b. Dependent Variable: Kemampuan Menyimak 


\section{Perhitungan Persamaan Garis Regresi Pengaruh Variabel $X_{1}$ dan $X_{2}$ terhadap Variabel Y}

Tabel 8. Coefficients ${ }^{a}$

\begin{tabular}{|c|c|c|c|c|c|c|}
\hline \multirow[b]{2}{*}{ Model } & & \multicolumn{2}{|c|}{$\begin{array}{l}\text { Unstandardized } \\
\text { Coefficients }\end{array}$} & \multirow{2}{*}{$\begin{array}{c}\text { Standardized } \\
\text { Coefficients } \\
\text { Beta }\end{array}$} & \multirow[b]{2}{*}{$t$} & \multirow[b]{2}{*}{ Sig. } \\
\hline & & $B$ & $\begin{array}{c}\text { Std. } \\
\text { Error }\end{array}$ & & & \\
\hline \multirow[t]{3}{*}{1} & (Constant) & 12.358 & 6.322 & & 1.955 & .057 \\
\hline & $\begin{array}{l}\text { Pengguna } \\
\text { an Media }\end{array}$ & .990 & .328 & .437 & 3.015 & .004 \\
\hline & $\begin{array}{l}\text { Gaya } \\
\text { Belajar }\end{array}$ & .681 & .246 & .402 & 2.768 & .008 \\
\hline
\end{tabular}

a. Dependent Variable: Kemampuan Menyimak

\section{Pengaruh Penggunaan media pembelajaran dan Gaya belajar Secara Besama-} sama terhadap Kemampuan menyimak bahasa Inggris Bahasa Inggris

Dari tabel di atas terlihat bahwa koefisien korelasi ganda pengaruh variabel bebas atas penggunaan media pembelajaran $\left(\mathrm{X}_{1}\right)$ dan gaya belajar $\left(\mathrm{X}_{2}\right)$ secara besamasama terhadap kemampuan menyimak bahasa Inggris (Y) adalah sebesar 0,794, hal tersebut menunjukkan tingkat korelasi yang sangat kuat.

Perhitungan pengujian signifikansi koefisien korelasi ganda ini bisa dilihat pada flag signifikansi (a) pada kolom R. Dari perhitungan tersebut di peroleh bahwa koefisien korelasi tersebut signifikan, dengan kata lain bahwa terdapat pengaruh yang signifikan variabel persepsi atas penggunaan media pembelajaran $\left(\mathrm{X}_{1}\right)$ dan gaya belajar $\left(\mathrm{X}_{2}\right)$ secara besama-sama terhadap kemampuan menyimak bahasa Inggris (Y).

Sedangkan koefisien determinasinya sebesar 63,1\% menunjukkan bahwa besarnya kontribusi variabel bebas variabel penggunaan media pembelajaran $\left(\mathrm{X}_{1}\right)$ dan gaya belajar $\left(\mathrm{X}_{2}\right)$ secara besama-sama mempengaruhi variabel terikat kemampuan menyimak bahasa Inggris (Y) sebesar 63,1\%, sisanya 36,9\% karena pengaruh faktor lain.

Sedangkan untuk pengujian hipotesis melalui analisis regresi diperoleh hasil perhitungan terlihat pada Tabel 4.7. dan Tabel 4.8, Dari Tabel 4.8. diperoleh persamaan garis regresi yang merepresentasikan pengaruh variabel $\mathrm{X}_{1}$ dan $\mathrm{X}_{2}$ terdahap variabel $\mathrm{Y}$, yaitu $\hat{Y}=12,358+0,990 \mathrm{X}_{1}+0,681 \mathrm{X}_{2}$.

Sedangkan pengujian signifikansi garis regresi tersebut adalah dengan memperhatikan hasil perhitungan yang ada pada Tabel 4.7. Menurut ketentuan yang 
ada, kriteria signifikansi regresi tersebut adalah "jika Sig $<0.05$ maka $\mathrm{H}_{0}$ ditolak" atau “jika $\mathbf{F}_{\text {hitung }}>\mathbf{F}_{\text {tabel }}$ maka $\mathrm{H}_{0}$ ditolak", yang berarti bahwa koefisien regresi tersebut signifikan, dengan kata lain terdapat pengaruh yang signifikan variabel bebas $\mathrm{X}_{1}$ dan $\mathrm{X}_{2}$ terhadap variabel terikat Y. Nilai Sig adalah bilangan yang tertera pada kolom Sig dalam Tabel 4.7.. Nilai $\mathbf{F}_{\text {hitung }}$ adalah bilangan yang tertera pada kolom $\mathbf{F}$ dalam Tabel 4.7.. Sedangkan nilai $\mathbf{F}_{\text {tabel }}$ adalah nilai tabel distribusi $\mathbf{F}$ untuk taraf nyata $5 \%$ dengan derajat pembilang $(\mathrm{k})=2$ dan derajat penyebut $(\mathrm{n}-\mathrm{k}-1)=48$ dimana $\mathrm{n}$ adalah banyaknya responden, dan $\mathrm{k}$ adalah banyaknya variabel bebas.

Dari Tabel 4.7. terlihat bahwa nilai Sig $=0,000$ dan $\mathbf{F}_{\text {hitung }}=40,163$, sedangkan $\mathbf{F}_{\text {tabel }}=3,195$. Karena nilai Sig $<0,05$ dan $\mathbf{F}_{\text {hitung }}>\mathbf{F}_{\text {tabel }}$ maka $\mathrm{H}_{0}$ ditolak yang berarti bahwa koefisien regresi tersebut signifikan. Dengan kata lain bahwa terdapat pengaruh yang signifikan variabel bebas variabel penggunaan media pembelajaran $\left(\mathrm{X}_{1}\right)$ dan gaya belajar $\left(\mathrm{X}_{2}\right)$ secara besama-sama terhadap variabel terikat kemampuan menyimak bahasa Inggris (Y).

Dari hasil pengujian korelasi maupun regresi tersebut maka disimpulkan bahwa terdapat pengaruh yang signifikan variabel bebas rasa variabel penggunaan media pembelajaran $\left(\mathrm{X}_{1}\right)$ dan gaya belajar $\left(\mathrm{X}_{2}\right)$ secara besama-sama terhadap kemampuan menyimak bahasa Inggris (Y).

\section{Pengaruh Penggunaan Media Pembelajaran Terhadap Kemampuan Menyimak Bahasa Inggris}

Dengan memperhatikan nilai/ bilangan yang tertera pada kolom $\mathbf{t}$ atau kolom Sig untuk baris Penggunaan media pembelajaran (Variabel $\mathrm{X}_{1}$ ) pada Tabel 4.8. Menurut ketentuan yang ada, kriteria signifikansi regresi tersebut adalah "jika $\mathbf{t}_{\text {hitung }}>$ $\mathbf{t}_{\text {tabel }}$ maka $\mathrm{H}_{0}$ ditolak" atau "jika Sig $<0,05$ maka $\mathrm{H}_{0}$ ditolak", yang berarti bahwa terdapat pengaruh yang signifikan variabel bebas $\mathrm{X}_{1}$ terhadap variabel terikat $\mathrm{Y}$. Nilai Sig adalah bilangan yang tertera pada kolom Sig untuk baris Penggunaan media pembelajaran (Variabel $\mathrm{X}_{1}$ ) dalam Tabel 4.8.. Nilai $\mathbf{t}_{\text {hitung }}$ adalah bilangan yang tertera pada kolom $\mathbf{t}$ untuk baris penggunaan media pembelajaran (Variabel $X_{1}$ ) dalam Tabel 4.8.. Sedangkan nilai $\mathbf{t}_{\text {tabel }}$ adalah nilai tabel distribusi $\mathbf{t}$ untuk taraf nyata 5\% dengan derajat kepercayaan $(\mathrm{df}=\mathrm{n}-2)=48$, dimana $\mathrm{n}$ adalah banyaknya responden. 
Dari Tabel 4.8. terlihat bahwa nilai Sig $=0,004$ dan $\mathbf{t}_{\text {hitung }}=3,015$, sedangkan $\mathbf{t}_{\text {tabel }}=2,011$. Karena nilai Sig $<0,05$ dan $\mathbf{t}_{\text {hitung }}>\mathbf{t}_{\text {tabel }}$ maka $\mathrm{H}_{0}$ ditolak yang berarti terdapat pengaruh yang signifikan variabel bebas $\mathrm{X}_{1}$ (penggunaan media pembelajaran) terhadap variabel terikat Y (kemampuan menyimak bahasa Inggris).

Dari hasil pengujian regresi tersebut maka bisa disimpulkan bahwa terdapat pengaruh yang signifikan variabel bebas $X_{1}$ (penggunaan media pembelajaran) terhadap variabel terikat Y (kemampuan menyimak bahasa Inggris).

\section{Pengaruh Gaya Belajar Terhadap Kemampuan Menyimak Bahasa Inggris}

Untuk membuktikan hipotesis tersebut adalah dengan memperhatikan nilai/bilangan yang tertera pada kolom $\mathbf{t}$ atau kolom Sig untuk baris penguasaan kosakta (Variabel $\mathrm{X}_{2}$ ) pada Tabel 4.8. Menurut ketentuan yang ada, kriteria signifikansi regresi tersebut adalah "jika $\mathbf{t}_{\text {hitung }}>\mathbf{t}_{\text {tabel }}$ maka $\mathrm{H}_{0}$ ditolak" atau "jika Sig < 0,05 maka $\mathrm{H}_{0}$ ditolak", yang berarti bahwa terdapat pengaruh yang signifikan variabel bebas $\mathrm{X}_{2}$ terhadap variabel terikat Y. Nilai Sig adalah bilangan yang tertera pada kolom Sig untuk baris gaya belajar (Variabel $\mathrm{X}_{2}$ ) dalam Tabel 4.8.. Nilai $\mathbf{t}_{\text {hitung }}$ adalah bilangan yang tertera pada kolom $\mathbf{t}$ untuk baris gaya belajar (Variabel $\mathrm{X}_{2}$ ) dalam Tabel 4.7. Sedangkan nilai $\mathbf{t}_{\text {tabel }}$ adalah nilai tabel distribusi $\mathbf{t}$ untuk taraf nyata $5 \%$ dengan derajat kepercayaan $(\mathrm{df}=\mathrm{n}-2)=48$ dimana $\mathrm{n}$ adalah banyaknya responden.

Dari Tabel 4.8. terlihat bahwa nilai Sig $=0,008$ dan $\mathbf{t}_{\text {hitung }}=2,768$, sedangkan $\mathbf{t}_{\text {tabel }}=2,011$. Karena nilai Sig $>0,05$ dan $\mathbf{t}_{\text {hitung }}>\mathbf{t}_{\text {tabel }}$ maka $\mathrm{H}_{0}$ ditolak yang berarti terdapat pengaruh yang signifikan variabel bebas $\mathrm{X}_{2}$ (gaya belajar) terhadap variabel terikat Y (kemampuan menyimak bahasa Inggris).

Dari hasil pengujian regresi tersebut maka bisa disimpulkan bahwa terdapat pengaruh yang signifikan variabel bebas $\mathrm{X}_{2}$ (gaya belajar) terhadap variabel terikat $\mathrm{Y}$ (kemampuan menyimak bahasa Inggris). 


\section{PEMBAHASAN}

Pengaruh penggunaan media pembelajaran dan gaya belajar secara bersamasama terhadap kemampuan menyimak bahasa Inggris

Persamaan regresi telah memenuhi persyaratan yang diperlukan antara lain variable dependen mengikuti distribusi normal, dan hasil uji linearitas diperoleh persamaan regresi variabel dependen terhadap variabel independen adalah linier.

Hasil pengujian diperoleh $F_{\text {hitung }}=40,163$ dan $F_{\text {tabel= }}$ 3,195, maka $F_{\text {hitung }}>F_{\text {tabel }}$. Hal ini menunjukkan variabel penggunaan media pembelajaran dan variabel gaya belajar secara bersama sama memiliki pengaruh yang signifikan terhadap variabel kemampuan menyimak bahasa Inggris. Selanjutnya, berdasarkan persamaan regresi ganda $\hat{Y}=12,358+0,990 \mathrm{X}_{1}+0,681 \mathrm{X}_{2}$, dapat diartikan setiap kenaikan satu unit persepsi atas penggunaan media pembelajaran dan sekaligus dengan kenaikan satu unit variabel gaya belajar akan diikuti dengan kenaikan kemampuan menyimak bahasa Inggris sebesar 1,68 unit $=(0,999+0,681)$.

Hasil pengujian hipotesis di atas menunjukkan bahwa telah terbukti terdapat pengaruh yang signifikan variabel penggunaan media pembelajaran terhadap variabel kemampuan menyimak bahasa Inggris, hal yang sama untuk variabel gaya belajar. Selanjutnya, secara bersama sama variabel penggunaan media pembelajaran dan variabel gaya belajar memberikan kontribusi terhadap variabel kemampuan menyimak

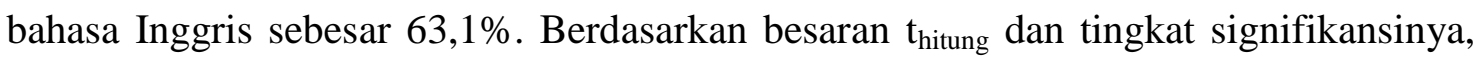
secara berurutan menunjukkan pertama adalah variabel penggunaan media pembelajaran, kedua variabel gaya belajar.

Berdasarkan informasi kuantitatif dan kualitatif dapat disimpulkan bahwa terdapat pengaruh yang signifikan persepsi atas penggunaan media pembelajaran dan gaya belajar secara bersama-sama terhadap kemampuan menyimak bahasa Inggris.

\section{Pengaruh penggunaan media pembelajaran terhadap kemampuan menyimak bahasa Inggris}

Berdasarkan hasil pengujian diperoleh $t_{\text {hitung }}=3,015>t_{\text {tabel }}=2,011$, dan sig $=$ 0,008 yang berarti kurang dari 0,05, sehingga dapat dinyatakan terdapat pengaruh yang signifikan antara variabel penggunaan media pembelajaran terhadap variabel kemampuan menyimak bahasa Inggris. Berdasarkan persamaan regresi ganda $\hat{\mathrm{Y}}=$ 
$12,358+0,990 \mathrm{X}_{1}+0,681 \mathrm{X}_{2}$, dapat diartikan setiap kenaikan satu unit penggunaan media pembelajaran akan diikuti dengan kenaikan kemampuan menyimak bahasa Inggris sebesar 0,999 unit, ceteris paribus atau variabel gaya belajar tidak berubah.

Dari informasi kuantitatif dan teori tersebut, dapat disimpulkan terdapat pengaruh yang signifikan penggunaan media terhadap kemampuan menyimak bahasa Inggris.

\section{Pengaruh gaya belajar terhadap kemampuan menyimak bahasa Inggris}

Berdasarkan hasil pengujian diperoleh $t_{\text {hitung }}=2,768>t_{\text {tabel }}=2,011$, dan nilai sig $=0,008$ yang berarti kurang dari 0,05 , Sehingga dapat dinyatakan terdapat pengaruh yang signifikan variabel gaya belajar terhadap variabel kemampuan menyimak bahasa Inggris. Menurut persamaan regresi ganda $\hat{\mathrm{Y}}=12,358+0,990 \mathrm{X}_{1}+0,681 \mathrm{X}_{2}$, dapat diartikan bahwa setiap kenaikan satu unit gaya belajar akan diikuti dengan kenaikan kemampuan menyimak bahasa Inggris sebesar 0,681 unit, ceteris paribus atau variabel penggunaan media tidak berubah.

Dari informasi kuantitatif dan teori tersebut, dapat diasumsikan bahwa terdapat pengaruh yang signifikan gaya belajar terhadap kemampuan menyimak bahasa Inggris.

\section{SIMPULAN DAN SARAN}

\section{Simpulan}

1. Terdapat pengaruh yang signifikan penggunaan media pembelajaran dan gaya belajar secara bersama-sama terhadap kemampuan menyimak bahasa Inggris. Hal tersebut dapat dibuktikan dengan nilai $\mathrm{F}_{\text {hitung }}=40,163>\mathrm{F}_{\text {tabel }}=3,195$, dan nilai sig $=0,000<0,05$. Variabel bebas penggunaan media pembelajaran dan gaya belajar secara bersama-sama menyumbang sebesar $63,1 \%$ terhadap variasi kemampuan menyimak bahasa Inggris.

2. Terdapat pengaruh yang signifikan penggunaan media pembelajaran terhadap kemampuan menyimak bahasa Inggris. Hal tersebut dapat dibuktikan dengan nilai $t_{\text {hitung }}(3,015)>t_{\text {tabel }}(2,011)$ dan nilai sig $=0,004<0,05$.

3. Terdapat pengaruh yang signifikan gaya belajar terhadap kemampuan menyimak bahasa Inggris. Hal tersebut dapat dibuktikan dengan nilai $t_{\text {hitung }}(2,768)>t_{\text {tabel }}$ $(2,011)$ dan nilai sig $=0,008<0,05$. 


\section{Saran}

1. Kemampuan menyimak bahasa Inggris pada siswa kelas XII Sekolah Menengah Kejuruan Swasta di Jakarta Pusat dalam penelitian ini dalam kategori cukup. Hasil penelitian ini menemukan bahwa nilai rata-rata adalah 66,62 dan masih ada $38 \%$ kemampuan menyimak bahasa Inggris siswa berada di bawah nilai rata-rata sehingga masih perlu ditingkatkan lagi.

2. Hasil penelitian menunjukkan variabel penggunaan media pembelajaran memiliki tingkat pengaruh yang lebih dominan dibandingkan dengan variabel gaya belajar. Untuk itu hendaknya peningkatan kemampuan menyimak bahasa Inggris tersebut dapat ditempuh dengan meningkatkan penggunaan media pembelajaran dan gaya belajar siswa secara lebih baik lagi.

3. Hendaknya diadakan penelitian lanjutan yang memasukkan variabel selain penggunaan media pembelajaran dan gaya belajar sebagai prediktor yang lebih lengkap bagi peningkatan kemampuan menyimak bahasa Inggris pada siswa.

\section{DAFTAR PUSTAKA}

Ahmad Rohani HM, 2004. Pengelolaan Pengajaran, Jakarta :RinekaCipta,

Asnawir dan Usman. 2002. Media Pembelajaran. Jakarta: Ciputat Press.

Bloom, Benjamin S. 1956.Taxonomy of Educational Objectives: The Classification of Educational Goals. London: David McKay Company, Inc

DePorter and Hernacki. 2009. Quantum Teaching. Boston: Allyn Bacon

Djamarah Syaiful Bahri, 2002. Psikologi Belajar. Jakarta : PT. RinekaCipta

Djamarah, Syaiful B. dan Aswan Zain. 2006. Strategi Belajar Mengajar. Jakarta: PT. RinekaCipta,

Ernest R. Hilgard. 1962. Theories of Learning. Englewood Cliffe, New Jersey: Prentice Hall Inc

Hamalik Oemar 1998 Metode Belajar dan Kesulitan Kesulitan Belajar Bandung Tarsito

Hornby, AS . 1987. Oxford Advancd Learner Dictionary of Current English. Britain. Oxford University

Muhibbin Syah 2000. Psikologi Belajar. Jakarta: Logos WacanaIlmu 
Research and Development Journal Of Education

Vol. 4 No. 2 April 2018

ISSN 2406-9744

Nababan Sri Utari Subyakto. 2003. Metodologi Pengajaran Bahasa. Jakarta : Gramedia.

Prayitno, Elida. 2001. Motivasi dalam Belajar. Jakarta: Depdikbud

R. Ibrahim \& Nana Syaodih. 2003. Perencanaan Pengajaran. Jakarta: RinekaCipta

Robbins, S.1998. Perilaku Organisasi :Konsep, Kontroversi dan aplikasi; Alih Bahasa :

Hadyana Pujaatmaka. Jakarta : PT Prenhallindo

Robert Mgagnedan J.1 Briggs. 1988. Principles Of Instructional Design, Second Edition (New York. Holt, Rinechardadn Wilson)

Safari 2004. Penulisan Butir Soal Berdasarkan Kurikulum Tingkat Satuan Pendidikan .Jakarta .Depdiknas

Shadily, Hasan. 2000. Ensiklopedia Umum. Jakarta :Kanisius

Sudirman A, M. 2004. Motivasi Belajar Mengajar. Jakarta : PT Raja GrafindoPersada.

Suharsimi Arikunto, 1988. Dasar-Dasar Evaluasi Pendidikan. Bumi Aksara, Jakarta

TIM Penyusun, 1985. Kamus Umum Bahasa Indonesia Jakarta: Depdikbud

W. S. Winkel. 1987. Psikologi Pengajaran, PT. Gramedia 